\title{
Tefenni Kurtarma Kazısından Çıkan İskeletlerin Antropolojik Analizi ve Bir Kafatası Deformasyonu Örneği
}

* Sorumlu Yazar / Corresponding Author: Ahmet İhsan AYTEK Burdur Mehmet Akif Ersoy Üniversitesi, Fen-Edebiyat Fakültesi Antropoloji Bölümü, Burdur / TÜRKIYE E-posta: aytek@mehmetakif.edu.tr

\section{Ahmet Ihsan Aytek ${ }^{*} \odot$, Alper Yener Yavuz ${ }^{2} \odot$, Orhan Özbey ${ }^{3} \odot$, Evren Şahin ${ }^{3} \odot$}

'Dr. Öğr. Üyesi | Burdur Mehmet Akif Üniversitesi, Fen-Edebiyat Fakültesi, Antropoloji Bölümü, Burdur / TÜRKiYE

${ }^{2}$ Arş. Gör. Dr. | Burdur Mehmet Akif Üniversitesi, Fen-Edebiyat Fakültesi, Antropoloji Bölümü, Burdur / TÜRKiYE

${ }^{3}$ Uzman | Burdur Müze Müdürlüğü, Burdur / TÜRKiYE
Alındı/Received: 19 Mayıs / May 2020 Düzeltildi/Revised: 4 Haziran / June 2020 Kabul/Accepted: 4 Haziran / June 2020 Yayımlandı/Published: 29 Haziran / June 2020

\section{$\ddot{O} z$}

Burdur ili, Pisidia bölgesinin önemli antik kentlerini barındırmaktadır. Yerleşimi Neolitik döneme kadar giden Burdur ilinde yapılmış ve halen yapılmakta olan kazılar, kentin geçmişine dair önemli veriler sunmaktadır. Buna rağmen, kentin geçmişini aydınlatacak antropolojik çalışmaların sayısı oldukça azdır. Bu çalışmada, Burdur ili Tefenni ilçesinde bir okul inşaatı esnasında tespit edilen ve Bizans dönemine tarihlendirilen nekropol alanından çıartılan insan iskeletlerinin antropolojik analizi gerçekleştirilmiştir. Kurtarma kazısı olarak yürütülen çalșmada nekropol alanının sadece küçük bir kısmında mezar açma işlemleri gerçekleştirilebilmiştir. İskeletler üzerinde yapılan antropolojik analizler sonucunda, 8 'i yetişkin ve 8 'i çocuk olmak üzere toplam 16 birey tespit edilmiștir. Bu bireylerin yașları ve boy uzunlukları belirlenmiș, ayrıca iskelet üzerindeki patoloji ve varyasyonlar da incelenmiştir. Bir bireyin femur ve coxae kemiklerinde ileri derecede artrit tespit edilmiştir. İskelet serisi içerisinde karșılaşılan en önemli durum, 11-12 yașlarında bir çocukta görülen kültürel kafatası deformasyonudur. İnsan etkisi ile kafatasının şeklinin değişmesine yol açan bu duruma ait bu örnek, antik dönem insanları için Burdur ilindeki ilk örnek durumundadır. Her ne kadar büyük bir iskelet serisi üzerinde gerçekleşmemiş olsa da, bu çalışma, az sayıda antropolojik çalışma ile temsil edilen Burdur ilinin antik geçmişine ait yeni bilgileri ortaya koymaktadır. Ayrıca, Tefenni ilçesinde Bizans dönemine ait çok fazla bilginin olmaması da bu çalışmanın önemini arttırmaktadır.

Anahtar Sözcükler: Tefenni, Burdur Müzesi, kurtarma kazıs1, nekropol, kültürel kafatası deformasyonu, paleopatoloji

\section{Giriş}

Burdur ili, sahip olduğu zengin arkeolojik geçmişi ile Anadolu'nun önemli antik dönem kentlerinden birisidir. Neolitik dönemden (Hacılar Höyük, Kuruçay Höyük, Höyücek Höyük) geç antik dönemlere (Balboura, Boubon, Kibyra, Kremna, Milias, Sagalassos ve Sia) kadar birçok önemli antik kenti bünyesinde bulundurmaktadır. Sahip olduğu arkeolojik yerleşim zenginliğine rağmen, Burdur ili az sayıda antropolojik
The Anthropological Analysis of Skeletal Material from Tefenni Salvage Excavation and an Example of Artificial Cranial Deformation

Abstract

Burdur hosts major ancient cities of Pisidia. Human occupation bistory goes back to the Neolitbic period and the archaeological excavations yield crucial data about the ancient history of the city. However, the number of anthropological studies, which can give important information about the history of city, is very low. In this study, anthropological examination was conducted on the skeletal remains unearthed from a Byzantine period necropolis. The necropolis is located in Tefenni district of Burdur province. Since it was a salvage excavation, just a small part of the area could be excavated. 16 individuals were identified in total, 8 adults and 8 sub-adults. Age at death and stature estimation were made, pathological conditions and variations were observed. A severe arthritis was detected on a femur and coxae of one individual. The most interesting condition is an example of artificial cranial deformation of an 11-12 years-old sub-adult. This buman-made cranial deformation is the first known example from ancient Burdur. Although the sample size of this study is relatively low, this study reveals anthropological results on ancient history of Burdur, which is not represented with a high number of anthropological studies. Furthermore, the fact that the archaeological data about the Byzantine period in Tefenni is low increases the importance of this study.

Key Words: Tefenni, Burdur Museum, salvage excavation, necropolis, artificial cranial deformation, paleopathology

çalışma ile temsil edilmektedir.

Burdur merkezde yer alan Kızılin Mağarası'nda bulunan ve Geç Tunç Çağı'na tarihlendirilen iskeletler üzerinde antropolojik çalışma gerçekleştirilmiştir (Yaşar vd., 2012). İskelet kalıntıları üzerinde yapılan antropolojik çalışmalar, iskeletlerin 3 erişkin ve 1 çocuk bireye ait olduğunu ortaya koymuştur. Erişkin bireylerden biri 35 yaşlarında bir erkek olarak tanımlanmıştır. Kadın olarak tanımlanan diğer iki 
bireyin ise yaş tahminleri yapılamamış, sadece erişkin olarak sınıflandırılmışlardır. Kadın bireylerden birisine ait humerus üzerinde Pearson formülü ile yapılan boy hesaplaması da, bireyin boyunun $148.8 \mathrm{~cm}$ olduğunu göstermektedir. Kemik ve dişler üzerinde yapılan patolojik incelemeler de; artirit, diş çürüğü, hypoplasia, apse, diş taşı ve alveolar kemik harabiyeti sorunlarını ortaya çıkarmıştır.

Diğer bir çalışmada ise, Gölhisar ilçesinde yer alan Kibyra antik kentinden çıarılan insan iskeletlerinin antropolojik analizi yapılmıştır (Sevim Erol vd., 2015). Yer altı oda mezarlar, Stadion, Odeon, Doğu Nekropol Anit Mezar ve Martyrion'dan, 137 bireye ait insan iskeletleri çıkarılmıştır. Bu bireylerin 64'ü yetişkin erkek, 35'i yetişkin kadın, 22'si çocuk olarak belirlenirken 16 bireyin cinsiyet tayini yapılamamıștır. Bireylerin yaş dağılımlarına bakıldığında ise, büyük çoğunluğun (\%73) genç ve orta yetişkinlerden oluştuğu görülmektedir. İskelet kalıntıları üzerinde gerçekleştirilen patolojik incelemeler ise travma, porotik hiperostosis, cribra orbitalia, enfeksiyonal hastalıklar, osteofit, Schmorl nodülü, osteoartirit, temporo-mandibular osteoartirite ait izler tespit edilmiştir.

Burdur ilinde kazısı devam etmekte olan diğer önemli bir antik kent de Ağlasun ilçesinde yer alan Sagalassos antik kentidir. Bu kent, Burdur ilinde antropolojik çalışma bakımından en zengin antik yer konumundadir.

Ricaut ve Waelkens (2008), gerçekleştirmiş oldukları çalışmada, kafatasının bazı özelliklerini kullanarak göç hareketlerine ait bilgileri ortaya koymaya çalışmışlardır. Çalışmada, Sagalassos antik kentinden çıkarılan ve radyokarbon yöntemi ile 11-13. yüzyıllara tarihlendirilen 37 yetişkin bireye ait kafatasları kullanılmıştır. Araştırıcılar, bu bireylerin tamamının aynı gömü özellikleri göstermesi nedeniyle, aynı kültürel özelliklere sahip olduğunu ve böylece muhtemelen aynı gruba ait olduğunu savunmaktadırlar. Kafatası üzerinde 17 farklı ölçülemeyen karakter belirlenmiş ve bu özellikler 27 farklı grup ile karşılaştırılmıştır. Çalışmanın sonuçları, bölgede birçok demografik hareketin olduğunu ortaya koymaktadır. Araştırmacılara göre, Sagalassos'da görülen biyolojik özellikler Güneybatı Anadolu'yu etkileyen önemli göç hareketlerinin izlerini taşımaktadır.

Yakın tarihli bir çalışmada, Cleymans ve ekibi (2018) kentin doğu nekropol bölgesindeki Roma dönemine tarihlendirilen bazı mezarların arkeolojik incelemelerini yapmış ve bazı antropolojik verilere de yer vermiştir. Yayında kremasyonlu üç birey, 18-21 yaş aralığında bir kadın birey, 25-40 yaş aralığında bir kadın birey, 30-40 yaş aralığında iki kadın birey, 20-50 yaş aralı̆̆ında bir kadın birey, 30-50 yaş aralığında bir kadın birey, 30-60 yaş aralığında iki kadın birey, 18-21 yaş aralığında erkek bir birey, 18-23 yaş aralığında erkek bir birey, 50 yaş üstü erkek bir birey, 20-40 yaşlarında erkek bir birey, 2550 yaş aralığında erkek bir birey, 30-50 yaş aralığında iki erkek birey, 30 yaşlarında erkek bir birey, 40 yaşlarında üç erkek birey, 30-60 yaş aralığında iki erkek birey, yaş ve cinsiyeti verilmeyen dört yetişkin birey, 20-40 yaşlarında cinsiyeti belirlenemeyen bir birey, 14-16 ve 16-17 yaş aralığında iki genç birey, 6-18 aylık bir bebek, 2-3 (2 birey), 4-5, 5-7, 10-12, 12-13 yaşlarında altı çocuk olmak üzere toplam 38 birey hakkında demografik bilgi verilmiştir.

Aynı yıla ait diğger bir çalışmada ise Bizans dönemine ait göğse takılan kolye haçların arkeolojik tanımlamaları yanında antropolojik verilere de yer verilmiştir (Cleymans ve Talloen, 2018). 1994 yılında aşağ1 Agora'nın batı yamaçlarında bir mezarlık alanı keşfedilmiş ve 2008 yılına kadar olan kazılarla bu alanın Apollo Klarios tapınağının doğu ve güney kısımlarına kadar uzadığ belirlenmiştir. Mezarlık alanı içerisindeki 58 mezar içerisinden 79 bireye ait iskelet kalıntıları tespit edilmiştir. Bir salgın hastalı̆̆ın veya depremin kurbanlarının gömülü olduğu düşünülen bu mezarlık alandan alınan üç iskelet örneğinin radyo-karbon tarihlemesi ise 11-13. yüzylllara işaret etmektedir. İncelenen 74 bireyin 46'sının 18 yaş altı olduğu belirtilmiştir. Bütün mezarların 32 tanesinde ise sadece 18 yaş altı bireyler, 17 tanesinde sadece yetişkin bireyler, 9 tanesinde ise yetişkin ve 18 yaş altı bireyler beraber bulunmuştur.

Antropolojik çalışmaların yanında, Sagalassos antik kentinde yapılan diğer önemli bir çalışmada ise, Roma ve Orta Bizans dönemine ait bireylerden alınan mitokondriyal DNA ile günümüzde Ağlasun ilçesinde yaşayan insanların mitokondriyal DNA verileri karşılaştırılmıştır (Ottoni vd., 2016). Çalışmanın sonucu, bölgede iki bin yıllık bir sürede genetik bir devamlılığın olmadığını ortaya koymuştur.

$\mathrm{Bu}$ çalışmada, Burdur ili Tefenni ilçesinde gerçekleştirilen kurtarma kazısından çıkarılan insan iskeletlerinin antropolojik analizi yapılarak, bölgenin geçmişine dair yeni bilgilerin ortaya konulması amaçlanmıştır.

\section{Gereç ve Yöntem}

Çalışmada, Tefenni ilçesinde yer alan Tefenni Meslekî ve Teknik Anadolu Lisesi bahçesinde gerçekleştirilen kurtarma kazılarında bulunan mezarlardan çıkarılan insan iskeletleri incelenmiştir (Resim 1). Kazı süresince toplam 34 mezar tespit edilmiş olup, bunlardan 18 tanesi açılabilmiştir. Açılamayan mezarlanın bir kısmında ağaç bulunduğundan, bir kısmında ise, dolgu toprağının kaldırılması esnasında okulun tuvaletinde veya başka bölümlerinde toprağın kaymasıyla hasar veya tahribatlar olabileceği düşünüldügünden, herhangi bir çalışma yapılmamıştır. Mezarlar, tipleri (çatkı kiremit), içerdikleri mezar hediyeleri ve alandaki bulgular 


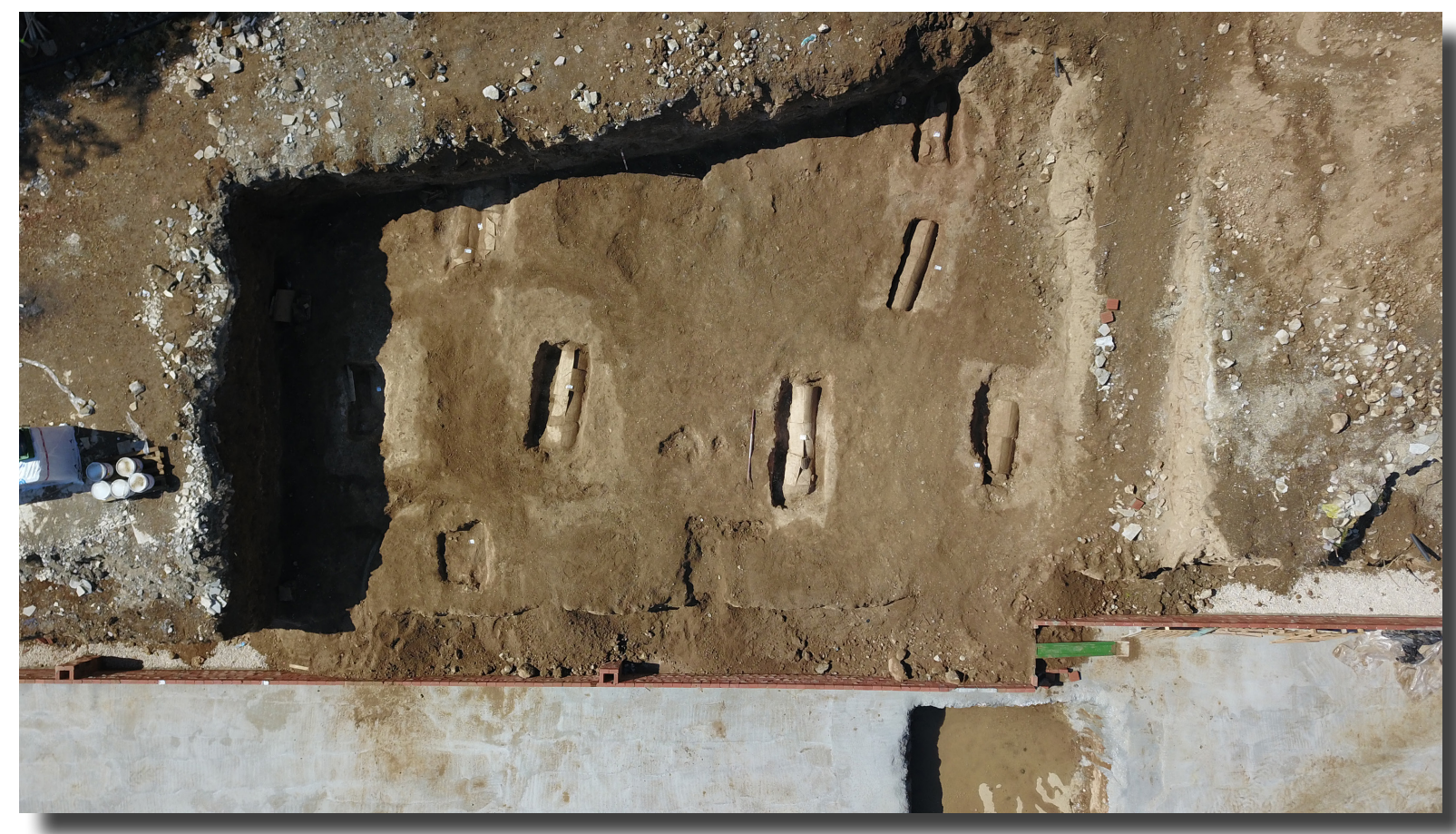

Resim 1. Kazı alanının kuş bakışı görünümü (Fotoğraf: Evren Şahin, Burdur Müze Müdürlüğü Arşivi)

göz önüne alındığında, Erken Bizans dönemine tarihlendirilmektedir (MS 4-7. yüzyıl). Kazının niteliği bakımından, insan iskeletlerinin çıkarılma işlemini müze uzmanlar1 ile beraber Burdur Mehmet Akif Ersoy Üniversitesi Antropoloji Bölümü öğretim elemanları ve öğrencileri gerçekleştirmiştir. İskelet öğeleri “iskelet çıarma teknikleri”"ne uygun olarak çıkarılmış olsalar bile, gömülüm süresince maruz kaldıkları fiziksel ve kimyasal etkilerden dolayı zarar gördükleri anlaşılmaktadır.

Burdur Müzesi tarafinda muhafaza edilen iskeletler, bu yayın çalışmasına bağlı olarak, verilen izin doğrultusunda, Burdur Müze Müdürlüğü’nden teslim alınarak Burdur Mehmet Akif Ersoy Üniversitesi Antropoloji Bölümü laboratuvarına getirilmiştir. İlk aşamada, kemikler üzerlerinde bilimsel analizler gerçekleştirmek için temizlenmiştir. Temizlenen iskelet öğeleri vücut kısımlarına göre ayrılarak bir masa üzerine yerleştirilmiş ve kırık parçaların birleştirilme işlemine geçilmiştir. Bu şekilde, daha bütün kemikler elde edilmesi ve daha fazla bilgi alınması amaçlanmıştır.

Çalışmada, minimum birey sayısı, yaş ve cinsiyet özellikleri ile kemikler üzerinde görülen patolojik durumlar ve varyasyonlar belirlenmeye çalışılmıştır. Bireylerin yaş ve cinsiyetleri, kemiklerin korunmuş durumdaki uygun k1sımları üzerinden literatürde belirlenmiş yöntemler kullanılarak, kafatası, mandibula, coxae, clavicula ve femur üzerinden değerlendirmesi yapılmıştır (The Workshop of European Anthropologists, 1980; Buikstra ve Ubelaker, 1994; Soni vd., 2010). Ayrica uzun kemikleri sağlam olan bireylerin boyları Pearson (1899), Trotter ve Gleser (1952) ve Sağır'ın (2000) boy hesaplama formülleri kullanılarak hesaplanmıstır. Son olarak tüm kemikler detaylıca incelenmiş ve kemikler üzerinde görülen patolojik durumlar ve varyasyonlar kayıt altına alınmıştır.

\section{Bulgular}

Kurtarma kazısı şeklinde gerçekleştirilen bu çalışmada mezarlara kod numaralanı verilmemiştir. Kod numarası verilmemiş mezarlardan çıan bireyler mezar sıralarına göre tarafımızdan numaralanmıştır. Bütün mezarlardan ele geçen iskelet öğelerine göre, alanda toplam 16 birey tespit edilmiştir.

Birey 1: Bireyin yaş1 11-12 olarak belirlenmiştir. Bireyin kafatasında kültürel deformasyon görülmektedir (Resim 2, 3). Bireyin kafasında, varyasyon örneği olan, 6 adet wormian görülmektedir. Bireye ait 14 diş tespit edilmiş olup, çene kemikleri ve dişlerde herhangi bir patoloji tespit edilmemiştir.

Birey 2: 1 numaralı birey ile aynı mezardan çıkarılmıştır. 1-2 yaşlarında olan bu bireyin kafatasında porotik bir yap1 söz konusudur.

Birey 3: Bireyin yaşı 0-6 ay olarak belirlenmiştir.

Birey 4: 3 numaralı birey ile ayn mezardan çıkarılmıştır. Bireyin yaşı 5-6 olarak belirlenmiştir. Kafatasında porotik yapı ve cribra orbitalia gözlenmektedir. Bireye ait 13 diş tespit edilmiş olup, çene kemikleri ve dişlerde herhangi bir patoloji tespit edilmemiştir.

Birey 5: Bireyin yaş1 5-6 olarak belirlenmiştir.

Birey 6: 5 numaralı birey ile aynı mezardan çıkarılmıştır. 36-43 yaş aralığında olan bu kadın bireyin kafatasında metopik sütur gözlenmektedir. Bireye ait 12 diş tespit edilmiş olup, çene kemikleri ve dişlerde herhangi bir patoloji tespit edilmemiştir. 5 ve 6 numaralı bireylerin çıkartıldığı mezar içerisinde yetişkin olmayan 


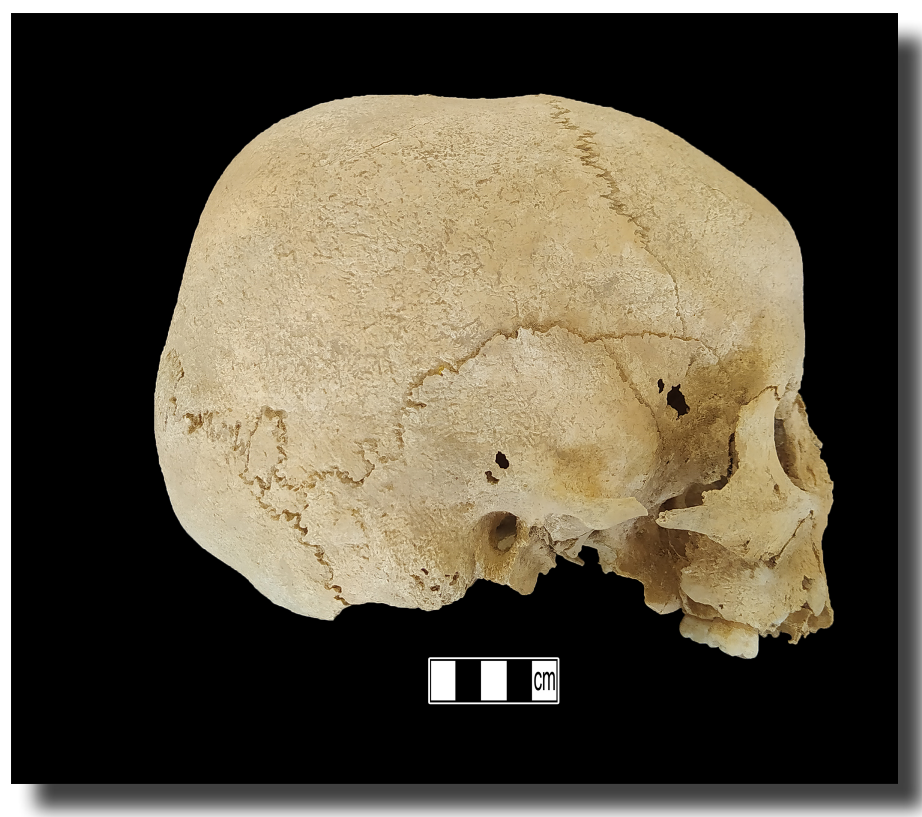

Resim 2. Kültürel kafatası deformasyonu, lateral görünüm.

bir domuza ait çene parçaları, keçiye ait diş, çene ve uzun kemik parçaları, sığıra ait boynuz, uzun kemik ve bilek kemiği parçaları da tespit edilmiştir.

Birey 7: 35-40 yaș aralığında olan erkek olan bu bireyin femur ve coxa kemiklerinde ileri derecede osteoartrit tespit edilmiştir (Resim 4).

Birey 8: Binanın asansör boşluğu için ayrılan kısmında açılan bir çukurda 9-10 yaşlarında bir bireye ait iskelet tespit edilmiştir. Bireyde tam bir metopik sütur mevcuttur. Bireye ait 3 diş tespit edilmiş olup, çene kemikleri ve dişlerde herhangi bir patoloji tespit edilmemiştir.

Birey 9: 34-47 yaş aralığında olan bu erkek bireyin

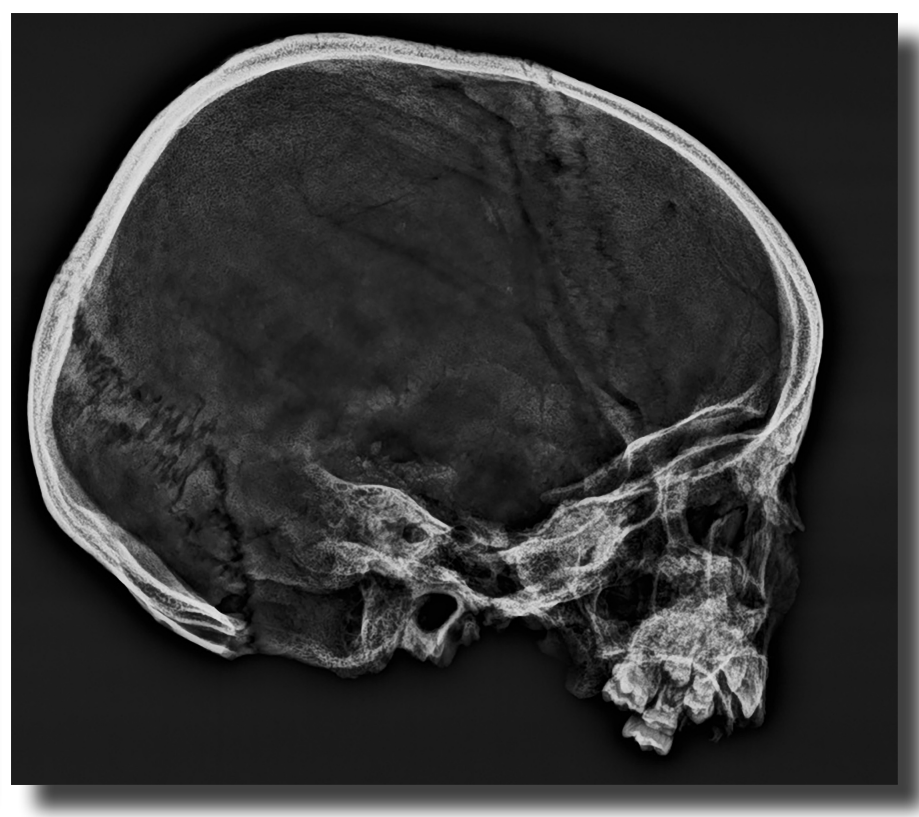

Resim 3. Kültürel kafatası deformasyonu, röntgen görüntüsü.

kemikleri çok iri ve kas yapışma izleri oldukça belirgindir. Ayrica, bu bireyin 26 adet omuru korunmuş olup, üzerlerinde 10 adet Schmorl nodülü tespit edilmiştir. Bireyin kütlesel yapısı ve omurlarındaki sorunlar, bireyin ağır bir işte çalıştığ şeklinde yorumlanabilir. Bireye ait 22 diş tespit edilmiş olup, çene kemikleri ve dişlerde herhangi bir patoloji tespit edilmemiştir. Bununla beraber, hem maksilla hem de mandibulada birer adet antemortem diş kaybı görülmektedir.

Birey 10: 44-50 yaşlarında olan bireyin cinsiyeti erkek olarak belirlenmiştir. Bireye ait 5 diş tespit edilmiş olup, çene kemikleri ve dişlerde herhangi bir patoloji tespit edilmemiştir. Mandibulada ise 6 adet antemortem (a)

प10 en

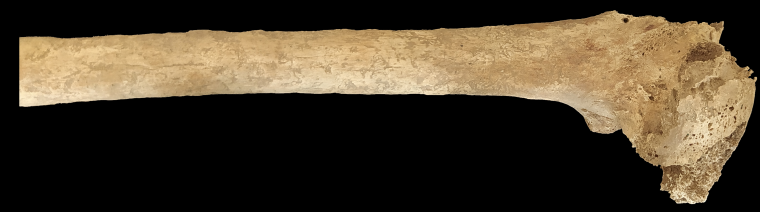

$0 . \mathrm{cm}$

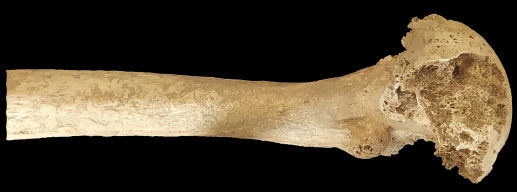

(c) (b)

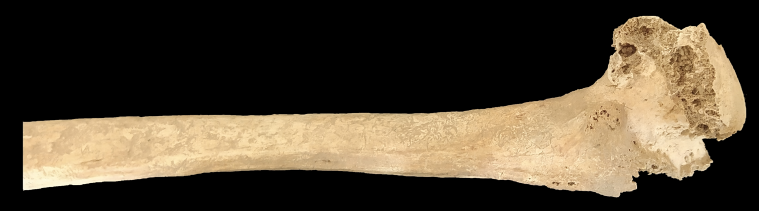

(d)

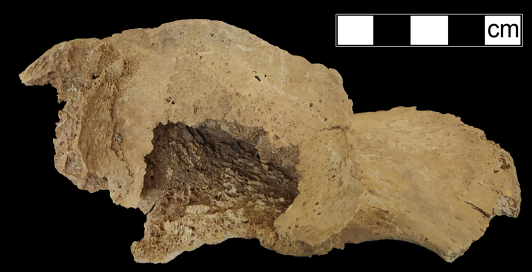

Resim 4. Alt ekstremitelerde artrit oluşumu. (a) femur, anterior görünüm, (b) femur, posterior görünüm, (c) femur, medial görünüm, (d) coxa. 
diş kaybı mevcuttur.

Birey 11: 43-50 yaş aralığında olan bu bireyin cinsiyeti kadın olarak belirlenmiştir. Bireye ait 9 diş tespit edilmiş olup, çene kemikleri ve dişlerde herhangi bir patoloji tespit edilmemiştir. Maksillada 2 antemortem diş kaybı mevcuttur.

Birey 12: 55-60 yaş aralığında olan bu bireyin cinsiyeti erkek olarak belirlenmiştir. 11 adet omur tespit edilmiş olup üzerlerinde herhangi bir patoloji mevcut değildir. $\mathrm{Bu}$ bireyin mandibulası bütün hâlinde korunmuştur. 2 tanesi hariç tüm dişlerin antemortem kayıp olduğu görülmektedir ki bu da ileri yaşın bir sonucu olarak ortaya çıkmaktadır.

Birey 13: 12 numaralı birey ile aynı mezardan çıkarılmışıı. Bireyin yaşı 10-11 olarak belirlenmiştir.

Birey 14: 30-35 yaş aralı̆̆ında olan bu bireyin cinsiyetinin erkek olduğu tespit edilmiştir. Bireye ait 24 diş tespit edilmiş olup, çene kemikleri ve dişlerde herhangi bir patoloji tespit edilmemiştir.

Birey 15: Bireyin yaşı 4-5 olarak belirlenmiștir. Bireye ait 5 diş tespit edilmiş olup, çene kemikleri ve dişlerde herhangi bir patoloji tespit edilmemiştir.

Birey 16: 39-42 yaş aralığında olan bu bireyin cinsiyeti erkek olarak belirlenmiştir.

\section{Yaş ve cinsiyet dağılımı}

Tespit edilen 16 bireyden 8 birey yetişkin, 2 birey bebek ve 6 birey ise çocuk olarak yaşlandırılmıştır. Yetişkin bireylerin hepsinin cinsiyet tayinleri yapılmış olup, 6 birey erkek ve 2 birey kadın olarak tespit edilmiştir. Erkek bireylerin yaş dağılımına bakıldığında ise; 1 erkek bireyin genç yetişkin (20-35), 4 erkek bireyin orta yetişkin (35-50) ve 1 erkek bireyin ileri yetişkin (50+) olduğu görülmektedir. İki kadın birey de orta yetişkin olarak sinıflandırılmaktadır (35-50).

\section{Boy}

Tespit edilen 16 bireyin 8 tanesi yetişkin olup, bu 8 bireyin 6 tanesinde boy tahmini yapilabilecek uzun kemikler mevcuttur. Pearson (1899), Trotter ve Gleser (1952) ve Sağır'in (2000) boy hesaplama formülleri kullanılarak her birey için üç boy hesaplaması yapılmıştır. Bunların ortalamalarına göre 5 erkek bireyin ortalama boyu $165,7 \mathrm{~cm}$ ve tek kadın bireyin boyu $151,6 \mathrm{~cm}$ olarak hesaplanmıştır. Bu 6 bireye ait boy verileri Tablo 1'de gösterilmektedir.

\section{Dental bulgular}

Dişler, sahip oldukları fiziksel ve kimyasal özellikler bakımından vücudun en dayanıklı kısımlarıdır. Bu yüzden, arkeolojik kazılarda en çok ele geçen vücut kısımlarının başında yer alırlar. Ancak bu çalışmada değerlendirilen malzemeler içerisinde çok az sayıda temsil edilmektedirler. Toplam 107 diş mevcut olup büyük çoğunluğu daimi dişlerden oluşmaktadır. Dişler veya çene kemikleri üzerinde herhangi bir patolojik durum görülmemektedir. Diş sayısının çok az olmasından dolayı, dişlerin aşınmalanı ile ilgili bir inceleme gerçekleştirilmemiştir.

\section{Tartışma}

Burdur ili, Pisidia bölgesinin önemli antik kentlerini barındırmaktadır. Tefenni ilçesinin arkeolojik geçmişi de, bölgede $80^{\prime} l i$ yıllardan itibaren gerçekleştirilen araştırmalarla ortaya konulmaktadır. Yapılan çalışmalar, bölgede yaşamın Kalkolitik döneme kadar gittiğini, hatta Neolitik döneme kadar gidebileceğini göstermektedir (Özsait, 1985). Bölgenin Tunç, Demir, Helenistik, Roma ve Bizans Çağı'nda da yerleşime açı olduğu, gerçekleştirilen yüzey araştırmaları ile ortaya konulmuştur (Özsait, 1985, 2006, 2007, 2008, 2009). Özsait (2006) Çaylı köyü yakınlarında bir nekropol alanının varlığını belirtse de, Roma dönemine ait lahitlerin büyük kısımlarının tahrip edildiğine değinmiş ve herhangi bir iskelet kalıntısından bahsetmemiştir. Diğer bir yüzey araştırmasında ise; yine Roma dönemine ait bir nekropol ile iki yerleşim yerinin bulunduğu ortaya konulmuştur (Özsait, 2007). Nekropolde bazı kemik buluntularının olduğuna değinilse de, antropolojik bir veri sunulmamıştır. Sonraki yüzey araştırmalarında da Tefenni ilçesinin birçok noktasında Roma dönemine tarihlendirilen kaya mezarları ve lahitler tespit edilmiştir (Özsait, 2007, 2008). Araştırmalarda birçok döneme ait izler tespit edilmiş olsa da, en çok örnekle temsil edilen dönemin Roma dönemi olduğu görülmektedir. Bizans döneminde kentin kullanıldığ 1 bilinmekle beraber, bu çalışmalarda Bizans dönemine ait bilgi sunulmamaktadır.

Kazıdan elden edilen iskeletler geniş bir demografik

Tablo 1. Uzun kemikler ile hesaplanan boy uzunluklar1

\begin{tabular}{ccccccc}
\hline Birey No & İskelet Öğesi & Cinsiyet & Pearson & Trotter\&Gleser & Sağır & Ortalama \\
\hline Birey 9 & Femur ve Tibia & Erkek & 161,3 & 164,3 & 164,1 & 163,2 \\
Birey 10 & Tibia & Erkek & 161,1 & 166,1 & 164,5 & 163,9 \\
Birey 11 & Femur & Kadın & 149,7 & 151,7 & 153,4 & 151,6 \\
Birey 12 & Radius & Erkek & 159,2 & 163,7 & 166 & 163 \\
Birey 14 & Femur ve Tibia & Erkek & 165,2 & 168,6 & 168 & 167,3 \\
Birey 16 & Femur ve Tibia & Erkek & 168,6 & 172,5 & 171,5 & 170,9 \\
\hline
\end{tabular}


bilgi edinilmesini mümkün kılmamaktadır. Az sayıda olsa da, boy uzunluğu verileri karşılaştırma için kullanılabilir. Antik toplumların boy uzunluklarının değerlendirildiği bir çalışmada Bizans dönemi için erkek boy ortalamas $167,9 \mathrm{~cm}$ ve kadın boy ortalamas1 $154,3 \mathrm{~cm}$ olarak bulunmuştur (Güleç, 1989). Başka bir çalışmada ise, erkeklerin boy ortalaması 169,5 $\mathrm{cm}$ ve kadınların boy ortalamas $158 \mathrm{~cm}$ olarak tespit edilmiştir (Koca Özer vd., 2011). Tefenni iskeletlerine ait yapilan boy uzunluğu hesaplamalarında ise, 5 erkek bireyin ortalama boyu $165,7 \mathrm{~cm}$ ve tek kadın bireyin boyu 151,6 cm olarak hesaplanmıştır. Bu veriler diğer iki çalışma ile karşılaştırıldığında, Tefenni bireylerinin boylarının Bizans dönemine göre kısa olduğunu ortaya koymaktadır.

Antik toplumlarda görülen kültürel uygulamalardan birisi de kültürel kafatasi deformasyonudur. $\mathrm{Bu}$ uygulama, bebeklik ya da çocukluğun erken evrelerinde kafatasının insan eliyle yapay olarak normal şeklinin dışında bir şekle dönüştürülmesidir. Bu durum bazen bilinçli olarak kafatası şeklinin istenilen bir şekle dönüştürülmesi şeklinde gerçekleşirken, bazen de başka bir kültürel öğenin etkisi ile ortaya çıkmaktadır. Bu tür deformasyonlar haricinde farkında olmadan kafatasının şeklinin değiştirilme işlemine ise yapay deformasyonlar denilmektedir. Örneğin, Anadolu'nun bazı yörelerinde bebeklerin tahta beşiğe yatırılması sonucu oluşmuş kafatasının arka kısmının gelişememesi durumu yapay deformasyonlara örnek olarak verilebilir (Özbek, 1982). Günümüzde hâlâ kafatası üzerinde kültürel deformasyon uygulamaları devam etmekle beraber, Neandertaller'de görülmeye başlanan bu uygulamalar (Trinkaus, 1982), Anadolu'da Neolitik Dönem'den itibaren görülmeye başlamış ve sonraki dönemlere tarihlendirilen arkeolojik alanlarda bu uygulamaların izine rastlanılmıştır (Yılmaz Usta, 2015). Kafa şekillendirme, kafatası modifikasyonu, kafa kalıplama, kafatası kültürel deformasyonu adı farklı bölgelerde farklı şekillerde isimlendirilse de genel olarak kültürel, politik veya sosyal amaçla uygulandığ1 bilinmektedir. Konuya cinsiyet açısından bakıldığında bazı bölgelerde yalnız kadınlara uygulanan bir işlem iken, diğer bazı yerlerde hem kadınlara hem de erkeklere uygulandığ1 görülmektedir. Sosyoekonomik olarak bakıldığında ise, genellikle, soylu sınıfın tercih ettiği bir uygulamadır denebilir. Örnek verecek olursak Misır'da Frig Kralı Midas, Lübnan'da Kral Tabnith gibi soyluların kafataslarında deformasyon işlemi uygulanmıştır (Alpagut, 1986). Kafa deformasyonu çeşitleri ise literatürde bilinen hâliyle çevresel ve yass1 kafa deformasyonları olarak iki ana başlıkta incelenebilir. Çevresel kafa deformasyonları tek ve çift bağlama olarak iki grupta incelenebilir. Yass k kafa deformasyonları da eğimli ve dik olarak yine iki grupta incelenebilir (Özbek, 1982).
11-12 yaşlarında bir çocukta görülen kültürel deformasyon örneği de çalışmanın önemli sonuçlarından birisidir. Zira Burdur ili için tespit edilen ilk örnek durumundadır. $\mathrm{Bu}$ birey üzerinde yapılan çalışmalar sonucunda çevresel bağlama tekniği uygulandığ1 tespit edilmiştir. Ayrıca bu işlem için tek bağ kullanılmış olup, bağın çene altından ve pariyetal kemiklerin üzerinden geçtiği düşünülmektedir (Resim 5, Tip A).

Bir bireyde porotik hiperostosis, bir bireyde ise porotik hiperostosis ve cribra orbitalia gözlenmiştir. Porotik hiperostosis, genellikle kafatasında gözlemlenen ve bazı durumlarda uzun kemiklerde de görülen bir doku bozukluğudur. Bu lezyonun ilk tanımlanması Welckler tarafindan 1885 yllında yapılmıştır (Goodman vd., 1984). Kafatasında pariyetal, oksipital ve frontal kemiklerde tahribata yol açtı̆̆1 gözlenen porotik yap1 yüz kutusunda ise orbitallerde görülmektedir. İlk olarak kafatasının dıș yüzeyinde başlayan tahribat doku kaybı ile devam eder. Benzer durumlar raşitizmde de görülebilmektedir (Uysal, 1993). Bu oluşum enfeksiyon kaynaklı ya da demir metabolizmasının ciddi şekilde bozulması sonucunda ortaya ç1kabilir (Şahin, 2016). Cribra orbitalia ise göz çukurlarının (orbital) tavan kısmında gözlenen ve genellikle irili ufaklı deliklerin oluşturduğu gözenekli yapıdır. İlk olarak 1888 yılında Welcker tarafindan eski dünya ve Güney Amerika topluluklarında tespit edilmiştir (Uysal, 1993). Bu lezyonun oluşumunda en önemi faktörün demir eksikliği anemisi olduğu düşünülmekte

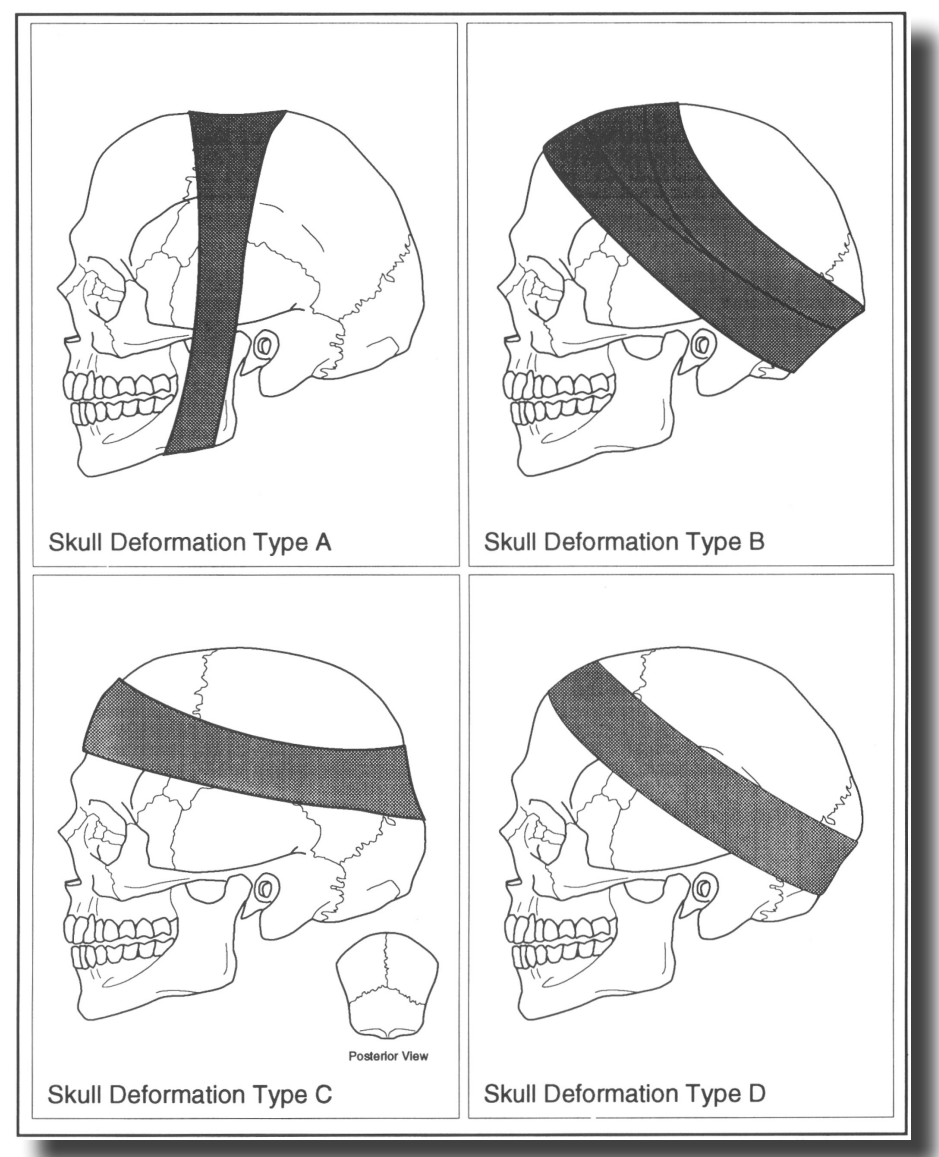

Resim 5. Çevresel tek bant bağlama şekilleri (Meiklejohn vd., 1992) 
ve kemik iliğinin fazla çalışması sebebiyle meydana geldiği ileri sürülmektedir. Göz çukurunda meydana gelen bu delikler bazı durumlarda birleşerek farklı yönlere uzanan yarıklar hâlinde de görülebilmektedir. Kemikteki görünümü porotik hiperostosis ile benzerdir fakat iskelet üzerindeki oluşum alanları farklıdır (Ortner, 2003; Şahin, 2016).

Cribra orbitalia yayılım derecesi ve gelişim durumlarına göre porotik, kribrotik, trabeküler ve kapalı trabeküler tip olmak üzere 4 farklı şekilde görülebilmektedir (Brothwell, 1981).

Yetişkin bir bireyde görülen osteoartrit ise, kabaca eklem kıkırdaklarının zarara uğraması ve yok olması sonucunda kemiklerde meydana gelen değişimlerdir. Bireyler yaşlandıkça eklem kıkırdakları değişime uğramaya başlar. Bu değişim genellikle önce kıkırdağın hareketli yapısını kaybetmesiyle başlamaktadır. Zaman içinde eklem içi sıvısı (sinoviyum) kıkırdakta meydana gelen tahribat nedeniyle iltihaplanır. Iltihaplanmayla birlikte kıkırdak daha fazla hasara uğramaya başlar ve eklemin doğal yapısı bozuldukça eski şeklini ve hareket kabiliyetini kaybetmeye başlar. Son aşamalarda ise osteofit adı verilen kemik çıkıntılar oluşmaya başlar ve böylece eklem bütün işlevselliğini kaybetmiş olur (Ortner, 2003; Şahin, 2016). Eklemlerde görülen osteroartirirtin oluşum sebepleri arasında yaş ve cinsiyet, kalıtımsal özellikler, aşırı kilo, travma ve bazı eklemlerin devamlı ve fazla kullanımı gibi birçok etken oldukça önemli rol oynamaktadır (Şahin, 2016).

\section{Sonuç}

Sonuç olarak, çalışmada ortaya konulan sonuçlar geniş çaplı bir demografik yorumlamaya imkân vermese de, antropolojik çalışmaların az olduğu bu bölgenin antik geçmişine ait yeni antropoloji verileri ortaya koymaktadır. Özellikle Burdur ili için ilk örnek olan kafatası deformasyonu önemli bir kayıt olarak ortaya konulmuştur. Ayrıca, Tefenni ilçesine ait Bizans Dönemi'nin arkeolojik verilerinin az olması da çalışmanın önemini arttırmaktadır. Devam etmekte olan Sagalassos ve Kybira antik kent kazıları ile ilerleyen yıllarda başlayacak olan kazılardan çıkarılacak iskelet kalıntıları üzerindeki çalışmaların yayına dönüştürülmesi ile beraber bölgenin antik dönemlerdeki demografik yapısı hakkında çok daha fazla bilgi ortaya konulacaktır.

\section{Teşekkür}

Çalışmaya konu olan iskelet malzemelerinin çalışılmasında bize her türlü kolaylığ gösteren Burdur Müze Müdürü Sayın Murat Kaleağasığlu'na candan teşekkürlerimizi sunarız. Örneklerin röntgenlerinin çekilmesinde yardımlarını esirgemeyen Burdur Mehmet Akif Ersoy Üniversitesi Veteriner Fakültesi öğretim elemanı Harun Çınar hocamıza da yardımlarından ötürü teşekkür ederiz. Ayrıca iskeletlerin çıkartılması, temizlenmesi ve çalışmaya hazır hâle getirilmesinde emekleri geçen öğrencilerimiz Büşra Aladağ, Buket Taş, Uğur Atahan Erkaya ve Kazım Kavrık'a da gayretli çalışmalarından dolayı teşekkür ederiz.

\section{Kaynakça}

Alpagut, B. (1986). Skeletons from Kurban Höyük-Urfa, Turkey. Anatolica, 13, 49-174.

Brothwell, D. R. (1981). Digging up bones: The excavation, treatment and study of human skeletal remains. Oxford University Press.

Buikstra, J. E., ve Ubelaker, D. H. (1994). Standarts for data collection from buman skeletal remains. Arkansas Archeological Survey Research Series No. 44.

Cleymans, S., ve Talloen, P. (2018). Protection in life and death: Pendant crosses from the cemetery of Apollo Klarios at Sagallasos, Turkey. European Journal of Archaeology, 21(2), 280298. https://doi.org/10.1017/eaa.2017.55

Cleymans, S., Talloen, P., Beaujean, B., Van de Vijver, K., ve Poblome, J. (2018). From burial to dump site: The history of the PQ4 compound at Sagalassos (southwest Anatolia). Anatolica, 44, 123-163. https://doi.org/10.2143/ANA.44.0.3285052

Goodman, A. H., Martin, D. L., Armelagos, G. J., ve Clark, G. (1984). Indicators of stress from bone and teeth. M. N. Cohen ve G. J. Armelagos (Ed.) içinde, Paleopathology and the origins of agriculture (s. 13-49). Academic Press.

Güleç, E. (1989). Paleoantropolojik verilere göre eski Anadolu bireylerinin boy açısından incelenmesi. Arkeometri Sonuclar Toplantısı, 5, 147-160. http://www.kulturvarliklari.gov.tr/ sempozyum pdf/arkeometri/05 arkeometri.pdf

Koca Özer, B., Sağır, M., ve Özer, İ. (2011). Secular changes in the height of the inhabitants of Anatolia (Turkey) from the 10th millennium B.C. to the 20th century A.D. Economics and Human Biology, 9(2), 211-219. https://doi.org/10.1016/j. ehb.2010.12.003

Meiklejohn, C., Agelarakis, A., Akkermans, P.A., Smith, P. E. L., ve Solecki, R. (1992). Artificial cranial deformation in the ProtoNeolithic and Neolithic Near East and its possible origin: Evidence from four sites. Paléorient, 18(2), 83-97. https://doi. org/10.3406/paleo.1992.4574

Ortner, D. J. (2003). Identification of pathological conditions in human skeletal remains. Academic Press. https://doi.org/10.1016/ B978-0-12-528628-2.X5037-6

Ottoni, C., Rasteiro, R., Willet, R., Claeys, J., Talloen, P., Van de Vijver, K., Chikhi, L., Poblome, J., ve Decorte, R. (2016). Comparing maternal genetic variation across two millennia reveals the demographic history of an ancient human population in southwest Turkey. Royal Society Open Science, 3, 150250. https://doi.org/10.1098/rsos.150250

Özbek, M. (1982). İnsan toplumlarında kafatası deformasyonları (Etnoantropolojik bir araştırma). Antropoloji, 11, 47-57. https://doi.org/10.1501/antro 0000000161

Özsait, M. (1985). 1984 y1lı Burdur-Isparta çevresi tarih öncesi sraştırmaları. Araștırma Sonucları Toplantısı, 3, 389-408. 
http://www.kulturvarliklari.gov.tr/sempozyum pdf/ arastirmalar/03 arastirma.pdf

Özsait, M. (2006). 2004 Y1lı Burdur İli Yüzey Araştırmaları. Arassturma Sonuclar Toplantısi, 23(2), 259-262. http://www. kulturvarliklari.gov.tr/sempozyum pdf/arastirmalar/23 arastirma 2.pdf

Özsait, M. (2007). 2005 yılı Burdur İli yüzey araştırmaları. Araştırma Sonuçları Toplantısı, 24(2), 463-478. http://www. kulturvarliklari.gov.tr/sempozyum pdf/arastirmalar/24 arastirma 2.pdf

Özsait, M. (2008). 2006 Y1lı Burdur ve Isparta İlleri Yüzey Araştırması. Araştırma Sonuclar Toplantısı, 25(2), 307-322. http://www.kulturvarliklari.gov.tr/sempozyum pdf/ arastirmalar/25 arastirma 2.pdf

Özsait, M. (2009). 2007 Y1lı Burdur, Isparta ve Antalya İlleri Yüzey Araştırması. Araștırma Sonuclar Toplantısı, 26(2), 357372. http://www.kulturvarliklari.gov.tr/sempozyum pdf/ arastirmalar/26 arastirma 2.pdf

Pearson, K. (1899). Mathematical contrubition on the theory of evolution: On the reconstruction of the stature of prehistoric races. Philosophical Transactions of The Royal Society, 192, 169-244. https://doi.org/10.1098/rsta.1899.0004

Ricaut, F. X. ve Waelkens, M. (2008). Cranial discrete traits in a Byzantine population and eastern Mediterranean population movements. Human Biology, 80(5), 535-564. https://doi. org/10.3378/1534-6617-80.5.535

Sağır, M. (2000). Uzun kemik radyografilerinden boy formülü hesaplaması. Yayımlanmamış Doktora Tezi. Ankara Üniversitesi Sosyal Bilimler Enstitüsü, Ankara.

Sevim Erol, A., Yavuz, A. Y., ve Tarkan, D. (2015). Teke yöresinde yaşamış bir antik dönem toplumunun antropolojik analizi. Ş. Kazan Nas (Ed). içinde, I. Teke Yöresi Sempozyumu Bildiriler Kitabı, 1. Cilt (s. 615-626). Mehmet Akif Ersoy Üniversitesi.

Soni, G., Dhall, U., ve Chhabra, S. (2010). Determination of sex from femur: Discriminant analysis. Journal of the Anatomical Society of India, 59(2), 216-221. https://doi.org/10.1016/ S0003-2778(10)80029-2

Şahin, S. (2016). Dilkaya toplumunun sağhlk sorunlar. Yayımlanmamış Doktora Tezi. Ankara Üniversitesi Sosyal Bilimler Enstitüsü, Ankara.

The Workshop of European Anthropologists (1980). Recommendations for age and sex diagnosis of skeletons. Journal of Human Evolution, 9(7), 517-549. https://doi. org/10.1016/0047-2484(80)90061-5

Trinkaus, E. (1982). Artificial cranial deformation in the Shanidar 1 and 5 Neandertals. Current Anthropology, 23(2), 198-199. https://doi.org/10.1086/202808

Trotter, M., ve Glesser, G. (1952). Estimation of stature from long bones of American Whites and Negroes. American Journal Physical Anthropology, 10(4), 463-514. https://doi.org/10.1002/ ajpa.1330100407

Uysal, G. (1993). Oylum Höyük Erken Tunç Că̆g çocuklarmm paleodemografik açıdan analizi. Yayımlanmamış Yüksek Lisans Tezi. Hacettepe Üniversitesi Sosyal Bilimler Enstitüsü, Ankara.
Yaşar, Z. F., Demirel, F. A., ve Çankaya, A. (2012) Burdur/ Kızılin Mağarası iskeletlerinin antropolojik açıdan değerlendirilmesi. C. Ü. Sosyal Bilimler Enstitüsü Dergisi, 21(2), 129-142. http://static.dergipark.org.tr/article-download/ imported/5000001592/5000002283.pdf?

Yılmaz Usta, N. D. (2015). Antik insanın sosyokültürel yaşamını yansıtan bazı diş ve iskelet sistemi anomalileri. International Journal of Social Sciences and Education Research, 1(2), 547-559. https://doi.org/10.24289/ijsser.106451

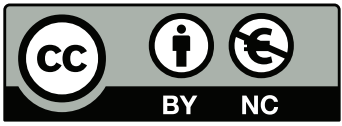

2020. Telif haklar1 yazar(lar)a aittir.

Bu makale Creative Commons Atıf-GayriTicari 4.0 Uluslararası (CC BY-NC 4.0) lisansının hüküm ve şartları altında yayımlanan açık erişimli bir makaledir. 